\title{
Global English Online - A Case Study of a Distance Learning Course in a Business Context
}

\author{
HELEN PETERS
}

Freelance educational consultant, UK

\section{Abstract}

The Open University in the UK, which has been providing distance education across the UK and continental Europe for the last 40 years, has recently started to develop an international strategy. New media allow for the creation of virtual learning spaces where students can learn from each other via the stimulus of materials from which they can draw according to their own perception of their needs. The challenge is to create materials appropriate for the range of possible student contexts. This paper explores the reaction of students to one such course in relation to the concept of lingua franca English, which is essentially pragmatic, developing within a particular context, for a particular purpose, and negotiated by those using it in that context.

\section{Introduction}

This paper is written in the context of an ever-widening expansion of English use and teaching around the globe and simultaneous development of the use of communication technology in educational and commercial contexts. The latter offers opportunities for distance teaching and learning across international borders which could meet the growing need for familiarity with English in the global business environment. However, a number of issues arise with regard to this including the implications for non-English speaking cultures and environments, the political dimension, and the question for teachers/learners/course developers of what English to teach and for whose purposes. This paper gives an overview of some of the recent writing on the issues and provides a case study of students in a distance learning English course aimed at meeting the needs of individuals involved in international business around the world.

\section{English in International Business}

David Crystal's (1997) work is well known for its celebration of the growth of English worldwide; however, Phillipson (as cited in Pennycook, 2007) considers that this growth is tied to "an uncritical endorsement of capitalism" (p. 19), describing English as a lingua economica. In the business world, English has spread the fastest as a means of day-to-day communication as opposed to a medium of education. Does this mean that when educators in the West teach English for business and on business courses they are spreading a particular business culture and promoting the interests of corporations? Connell (as cited in Smith, 2006) refers to a tension between loyalty to the nation and the internationalisation of capitalism and refers to Ghosh's (1992) "suggestion that business can serve as its own form of communication, one which transcends existing cultural differences" but also "seems to afford trade a privileged status that elevates it above other forms of social interaction" (p. 176). However, this form of communication, in business, generally manifests itself via the medium of English as described below. 
Kankaanranta and Louhiala-Salminen (2010) observe that globally operating business professionals seem to need two languages to work - their mother tongue and English - and they contend that $80 \%$ or more of the daily English business communication in the world takes place in non-native English. In multi-national corporations, somebody decides what language will be used to best benefit the corporation (Luo \& Shenkar, 2006). These decisions are supposedly made on an economic rather than ideological basis, although Luo and Shenkar (2006) say that Japanese multi-national corporations tend to use Japanese even in subsidiaries in other countries because of their concern with "value homogeneity" and their "high power distance" culture (p. 331). However, when choices have to be made in the case of mergers it seems to be the exception rather than the rule if English is not the language chosen. This phenomenon has given rise to the term Business English as a lingua franca (Louhiala-Salminen \& Kankaanranta, 2005). Business English as a lingua franca is a language in which there are no native speakers or non-native speakers and no learners, but, rather than being "neutral" or "cultureless", it acts as "a conduit of its speaker's culture" (p. 417).

Louhiala-Salminen and Kankaanranta (2005) suggest that in Business English as a lingua franca learners should be taught to see themselves as communicators with real jobs to perform and needs to fulfil and that the emphasis should be on the actions involved rather than on the language used to carry them out. In this suggestion, Louhiala-Salminen and Kankraanta (2005) see learners as using language to constitute identities rather than reflect those that already exist. This perspective is in accordance with Pennycook (2007) who has developed the notion of performativity which brings into view "the production of an identity in the making" (p. 71) to describe this process. The objective of business English classes would therefore be to enable individuals to carry out the functions involved in their work rather than to develop their knowledge of language. Pennycook (2007) thus argues for "a theory of how social transformation operates through linguistic use rather than seeing all language use as mirroring the social" (p. 69). In his view, "identities are formed in the linguistic performance rather than pregiven" (p. 76) and performance is interactive. A "move from the performative to the transformative is crucial for an understanding of performativity as neither merely the playing out of public roles nor the acting out of sedimented behaviour, but the refashioning of futures" (p. 77). Kramsch (as cited in Ricento, 2000) likewise suggests that "English may have effects in terms of the cultural baggage that comes with [it] but...can have no absolute or necessary effects [because] 'third' cultures or 'third spaces' are constantly being created" (p. 118). These ideas move away from the concept of knowledge of English as an educational asset to one of functionality and achievement of practical aims.

This section has focussed on changes in attitudes to English language teaching and learning as a result of the expansion of English as a business language. The perceptions of language expressed in the literature mentioned are that the use of English in the business world is construed by learners as a means to an end and a creative tool for the achievement of practical activity and exchange of ideas. The next section will consider the educational implications of this.

\section{Implications for Teachers and Learners}

It follows from the above that courses aimed at students operating or planning to operate in an international business environment should reflect the diverse contexts of the students and the language needed for work in multi-national business 
organisations. At the same time different management and organisational cultures, the local context, and the wider world context need to be taken into account. The concepts expressed below informed the development of the course, which forms the context of the case study in this paper, and gave rise to the questions the paper seeks to answer. Going global, aiming for an international market for courses, has implications for the product, the courses, content, and methodology. Sonaiya (2002) points out that, "A teaching method is a product of the society in which it was developed; that is, teaching methods are cultural products" (p. 107). Is it possible to produce teaching material or courses that are globally relevant? Cultural assumptions are made in course production and these may disadvantage certain students, for example when producers, wittingly or unwittingly, see a binary divide between western and other cultures in which the other is seen as an add-on to the main western culture. Can there genuinely be a "blurring of the cultural and economic distinctions between the inhabitants of industrialised countries in the West and those of industrialising countries in Africa, Asia, and Latin America" (McCarthy, Giardina, Harewood, \& Park, 2003, p. 462)? When courses are designed by and for people studying in a Western/European context - for example the United States, Australia, Canada, New Zealand, and countries in the European Union-what effect does this have on students from other contexts? Yakhontova (2001) describes how Ukrainian students were "surprised not to find anything relevant to the cultures of their part of the world, with the exception of one small sentence devoted to the Russian language" (p. 405) in a U.S.-based English for Academic Purposes writing textbook.

Are students disadvantaged by any mismatch between assumptions made in course production and their own learning situation? There is evidence that they do not achieve on a par with students familiar with the culture and that they may feel uncomfortable and disconcerted by the world view they are forced to accommodate. Goodfellow, Lea, Gonzalez, and Mason (2001) researched student performance on a UK Open University internationally marketed MA program and found that students identified as linguistically and culturally other (i.e., not UK) gained lower average assessment scores across the program. Sonaiya (2002) suggests that this may be related to methodology in teaching, since in the case of "educational materials alleged to be suitable for global dissemination," learners from different cultural contexts may find themselves forced "to adopt modes of behaviour that are incompatible with [their] fundamental ways of being" (p. 114).

Advocates of English as a lingua franca see language as practice and performance, with the aim of "interpret[ing] communication of novices in context without comparing it with norms or target" and "proficiency, versatility and agility not mastery and control" (Jenkins, 2007, p.21). Advocates argue for the development of language through shared activities and interests to be accomplished via a practicebased model. Canagarajah (2007) also describes language acquisition in the context of lingua franca English as "not a cumulative process, but an ability to come up with diverse strategies for speech events that need to be addressed for their own sake" (p. 932).

The emergence of regional and global discourse communities has been facilitated by the rapid increase in digital communication which enables the intermingling of the local with the global on a daily basis. Norms of communication in the global online world are not necessarily driven by native English speakers (Baker, 2009), so that the "need in English as a lingua franca [is] to focus on the types of communication strategies typically associated with multilingual communities" ( $p$. 
588). The implication of this is that teachers might move away from inculcating in students the need to speak like a native speaker and de-Anglo-Americanise and internationalise the language (Berns et al. as cited in Hoffman \& Siebers, 2009). These are some of the considerations we engaged with when starting to develop English courses at the Open University.

\section{The Open University}

The Open University (OU) in the UK was founded with the ethos that higher education should be accessible to all, successfully opening it up to a wide social spectrum, including a section of the local population who have come from different cultural backgrounds/education systems. However, research into ethnicity and academic attainment shows that "white students are two and a half times more likely to obtain a good pass on courses in comparison to Black students, and White students outperform all ethnic minority groups" (O'Shea-Poon, Erling, Richardson, \& Hawkins, 2009, p. 1). There is "a strong relationship between English language competency and academic attainment" (p. 2). Eight percent of white undergraduates and $20 \%$ of white postgraduates and $50 \%$ of black undergraduates and $35 \%$ of black postgraduates, have a first language other than English. "Continued inward migration, international expansion and an increased focus on widening participation are likely to widen the ethnicity attainment gap" (p. 7). Hitherto, the OU has offered education mainly for people living in the UK or continental Europe, operating within an EEC, Western, developed culture, even if many of the students come from other backgrounds. The OU's International Strategy describes the current OU experience as "UK-centric with little adaptation to international markets" (Open University, 2010, p. 2). It goes on to state that developing courses for an international market requires the ability to create quite different courses that meet local needs "while retaining the OU's 'secret sauce" (p. 3) and "distinctive capabilities in supporting distance learning" (p. 4). Some OU courses are already run in other countries through international partners, for example in Russia and Ethiopia, as part of validated programmes, however, the courses were not developed specifically for this purpose, and it has been recognised that they may sometimes be ill adapted for the student groups studying on them.

OU courses are complete packages based on the principle that a student can succeed in total physical isolation if they so wish, since all spoken contact in the form of tutorials is optional. In an online teaching situation, students with different linguistic backgrounds and working environments could be situated in different contexts around the globe. LB720, English Communication Skills for Global Managers, the course examined in this paper, was created with the aim of being needs/purpose analysis-based, orientated to language in context, and orientated to a diverse student body. This might include L1 and L2 speakers of English, students from diverse educational backgrounds, U.K.-based and non-U.K.-based students, and students at different levels in the same group. Bearing in mind that the only thing the students might have in common could be the need to function in business through the medium of English, the study identified the following questions: (a) Would it be possible for the students to form a successful virtual community for the purpose of study? (b) Would the course materials developed for the course fulfil their intended purposes in the eyes of the students?

Underlying these questions was Sonaiya's (2002) point that teaching methods are cultural products, and the issue of catering for a wide range of cultures among 
students. Would students genuinely be forming new identities as Pennycook (2007) suggests, or would they be struggling to conform to a perceived way of behaving? Would students be able to use Business English as a lingua franca as a conduit of their own culture (Louhiala-Salminen \& Kankaanranta, 2005) and to achieve their own aims through the course materials and interaction with the tutor and their fellow students?

\section{The Course Aims}

LB720 is the first OU course aimed specifically at a global clientele. It targets students considering taking a Masters in Business Administration and anyone working in a managerial context needing or wanting to operate through the medium of English. The key aim is to enable students to communicate comfortably in a business environment, at a distance, with people around the world. The central premise is that by participating, the students will establish relationships with people working in similar environments to them and become practised in communicating via a range of technological facilities available: online forums, Elluminate (a meeting/teaching facility which enables simultaneous group interaction with interactive visual affordances), email, or Skype. The distance-learning dimension aimed at enabling the creation of communities across geographic boundaries: "the learning that is most personally transformative turns out to be the learning that involves membership in... communities of practice" (Wenger as cited in Leki, 2007, p. 121), but at the same time it has its own cultures which may exclude some on a technological/psychological basis. Lukhele (2004) has described the kinds of issues that may affect students on the African continent; for example, with unreliable electricity supplies or lack of access to any electronic communication, and, even where access to internet cafés is freely available, students who do not have their own PC may feel themselves to be at a disadvantage. The course requires students to complete tasks collectively through group activity including for assessment purposes. Leki (2007) has emphasised the importance of group activity in fostering "socioacademic" (p. 47) relationships and this activity necessarily takes place online. There are regular (optional) online tutorials and students have access to audio/visual materials. These aim to equip them with the linguistic resources to enable them to perform a range of tasks, whether study related or outside the study context.

\section{The Course Materials}

The materials reflect a range of business situations and contexts, with the aim of broadening the possibility of students identifying with them and avoiding the effect of a cultural divide, as described by Yakhontova (2001). For this reason, the materials draw on examples from India, Indonesia, Poland, Ivory Coast, Nigeria, South Africa, Russia, and China, as well as US and Western European case studies. Listening material uses different accents to convey the message that there is not one correct way of speaking English, but that many variations are acceptable. Jenkins (2007) found that, "Language based discrimination is particularly evident at the level of accent [which] seems to elicit the most negative views of non-native Englishes" (p. 59). We hoped that listening to audio text spoken in a range of accents, as well as communicating in English regularly with people from many different language backgrounds, would instil acceptance of variations and encourage a pragmatic approach. Louhiala-Salminen and Kankaanranta (2005) found that finding the right expressions in "ordinary small talk" (p. 407) or acting assertively in negotiations were 
described as difficult by people in business using English, along with using the telephone and "being prepared to suddenly and effectively express opinions or convey nuances" (p. 407). Regular synchronous online discussions were thus timetabled, with or without a tutor present, and students had to participate in these discussions to complete the assessment tasks.

Taking a Hallidayan (1994) approach, analysing language from textual, ideational, and interpersonal perspectives, the course aimed to familiarise the students with the use of language across multiple interconnecting contexts: the business context, relating the students' work on the course closely to their current or recent employment and, in particular, to aspects of management; the international context, relating the case studies used and the students' own experience to their own and other's locations, whether in their own or a third country; the online context, relating the language used to the different online media in which it occurred, with their different affordances; and finally, the academic context, the language of study, and the metalanguage necessary for raising awareness of how language is used in the above contexts and how it can be learned. The context of study was thus simultaneously local and global, each student being located on the course, in the virtual student community, as well as in their own workplace community in whatever country they were based.

\section{The Approach}

The course uses case studies for teaching/learning. Students are provided with a range of case studies illustrating different ideational meta-functions, such as cause and effect, conflict, problem solving, and scenario planning, expressed via genres. The genre approach involves a cycle of deconstruction/joint construction/independent construction, whereby students analyse content and collaboratively reproduce it before proceeding to the independent stage where they are in command of text construction. The deconstruction phase involves analysis of the language of the text within the context, thus giving the students the tools to subsequently carry out their own analysis and construct their own texts. There is an emphasis on collaboration at all stages (including in assessed work), and the activities - which are oriented towards students' own work situations - aim at enabling them to meet assessment criteria related to the achievement of practical objectives rather than specifically language related. Whether in the case of spoken, written, group, or individual tasks, criteria are focused on successful completion of tasks rather than on grammar or pronunciation.

Each of three course assignments asks students to look at one or two texts and draw information from them to produce a written report and a spoken presentation with a specific practical aim. The End-of-Course Assessment consists of a report written by three or four students as a group based on information gathered from four or five given texts; an individual evaluation of the process; and an online discussion in which each student is required to present a point of view, followed by a discussion. All material consists of real texts from business contexts-written and spoken.

\section{The Students}

The two cohorts in the course were very small: four and 15 students respectively. In the first cohort the students were located in their home countries: France, the UK, and Slovenia (except for a Turkish student based in the UK). In the second cohort, few of the students were located in their country of origin. Of those who completed, there were five students in Japan: four Japanese and one Haitian. 
Three of these students (two of the Japanese students and the Haitian student) were based in Tokyo and worked for the same company, and they worked on the course as a group. The others were an Iranian based in Dubai, an Italian based in Sweden, an Italian based in Luxembourg, a German based in Germany, a Russian based in Russia, and a Polish, an Argentinian, and a French student based in the UK. Thus, more than half of the students were already operating in several languages and participating in local communities distinct from their original home environments.

\section{Methodology}

A case study approach was adopted to obtain an overview of the contexts within which the students were studying and a measure of the effectiveness of the course materials and tuition methods, in their terms. The reasons for the choice of case study were, firstly, the data were very limited because the course had only run twice and with small numbers of students. Secondly, there was a range of different kinds of data involved including numerical data concerning four students on the second presentation of the course, qualitative data collected from two students on each of the presentations via interviews, and data provided by all the students in the form of their assignments and end of course assessments. The interviews and assignments give insights into how four students perceived the course and their own achievements on it, while the analysis of the students on the second cohort's evaluations of their assessment set the interview data in a broader context. Here, it is possible to get an idea of how the students interacted in groups and what they learned from this aspect of the course. Permission was gained from the University Student Research Project Panel (SRPP) and consent given from the students for the use of all data. The author and a colleague developed the course, but neither of them taught on it, although the author acted as a monitor to the tutor on both presentations. Monitoring in the context of the Open University entails being a second marker on a sample of all work submitted for assessment, including listening to recordings of oral work.

\section{The Questionnaire}

The questionnaire (see Appendix 1) was a standard OU questionnaire for students, administered electronically as part of a routine course survey, adapted to take account of the methods of tuition (Tutor Group Forum, Elluminate, Audio-visual aids, online activities). Questions four, eight, and ten were not considered relevant to the issues discussed in this paper and the students' responses to these have not been included. For questions 13, 14, 16, 17, and 20, no responses were received.

\section{The Interviews}

The interviews with two students on the first presentation of the course were carried out by the OU Learning and Teaching Development team, who determined the questions (see Appendix 2). The responses were subsequently written up in the form of a report to the faculty, which is drawn on in the account of the first interviews below. The interviews with two students on the second presentation were carried out by the author on Skype using questions (see Appendix 3) devised by her and approved by the SRPP. Because these students had already completed the questionnaire, it was possible to omit a large number of the questions asked in the interviews with the first cohort and to focus on the individual students' experiences in more depth. During these interviews notes were taken and checked with the students concerned. 


\section{Student data}

The author had access to all assignments and end-of-course assessments produced by the students. This material included student self-assessment of their individual and group performance, and their own evaluation of their End-of-Course Assessment.

\section{The Questionnaire}

\section{Results}

Four students in the second cohort responded to the questionnaire and their answers are summarised in Table 1.

Table 1

LB720 English communication skills for global managers - post module questionnaire

\begin{tabular}{|l|l|l|}
\hline Question & Response & Number \\
\hline $\begin{array}{l}\text { Q 1 Is English your first } \\
\text { language? }\end{array}$ & No & 4 \\
\hline Q 2 What was your motivation? & Career development & 2 \\
\hline & Language & 3 \\
\hline & Personal interest & 2 \\
\hline $\begin{array}{l}\text { Q 3 How does the course fit with } \\
\text { your current study plan? }\end{array}$ & $\begin{array}{l}\text { I am studying to help in my current } \\
\text { employment }\end{array}$ & 4 \\
\hline & I am planning future study & 4 \\
\hline Q 5 How often do you use these? & Personal computer or laptop & 4 \\
\hline & Broadband & 3 \\
\hline & i-phone & 2 \\
\hline Q 6 Where do you study? & Library, internet café or dial-up & 1 \\
\hline & At home and sometimes at work & 4 \\
\hline $\begin{array}{l}\text { Q 7 How have you found the } \\
\text { academic level? }\end{array}$ & Library or internet café & 1 \\
\hline $\begin{array}{l}\text { Q 9 Do you agree or disagree } \\
\text { with the following? }\end{array}$ & About right & 4 \\
\hline & I feel part of a student community & 4 \\
\hline $\begin{array}{l}\text { Q 11 How useful have you found } \\
\text { the following? }\end{array}$ & $\begin{array}{l}\text { I was able to access the course online } \\
\text { when needed }\end{array}$ & 3 \\
\hline & Main course materials: Useful & 4 \\
\hline & Audio and video clips: Quite useful \\
\hline & Elluminate tutorials: Useful & 2 \\
\hline & Online activities: Not very useful & 1 \\
\hline & & 2 \\
\hline
\end{tabular}




\begin{tabular}{|l|l|l|}
\hline & Collaborative activities: Very useful \\
& \multicolumn{1}{|c|}{ Not very useful } & 2 \\
\hline $\begin{array}{l}\text { Q 12 How easy or difficult have } \\
\text { you found the assessment? }\end{array}$ & Neither easy nor difficult & 3 \\
\hline & Not very easy & 1 \\
\hline $\begin{array}{l}\text { Q 15 How useful have you found } \\
\text { the language? }\end{array}$ & Useful & 4 \\
\hline $\begin{array}{l}\text { Q 18 Do you agree with the } \\
\text { following? }\end{array}$ & $\begin{array}{l}\text { I am satisfied with the discussion in the } \\
\text { Tutor Group Forum }\end{array}$ & 4 \\
\hline & I am satisfied with the online tutorials & 4 \\
\hline $\begin{array}{l}\text { Q 19 How do you get help in } \\
\text { your studies? }\end{array}$ & Emails to the tutor & 4 \\
\hline & Phone calls to the tutor & 2 \\
\hline & Elluminate tutorials & 3 \\
\hline & Friends and colleagues & 3 \\
\hline $\begin{array}{l}\text { Q 21 Do you agree with the } \\
\text { following? }\end{array}$ & I am satisfied with the course & 4 \\
\hline & I would recommend it to others & 4 \\
\hline
\end{tabular}

The responses confirm the student focus on the workplace, and it is useful to see that they found the academic level appropriate and the course materials useful. They also demonstrate satisfaction with the course and with the online tutorials; however, there are differences in reactions to the various other media of teaching and learning. It is not possible to know whether the two students who found the audio and video clips "not very useful" are the same two who found the Elluminate tutorials, the Tutor Group Forum, and the online and collaborative activities "not very useful". The answers do not give any indication as to whether technical difficulties might have caused dissatisfaction with these elements, especially as one respondent was accessing the course mainly via a public library or internet café. The interviews, described below, shed some light on why certain students might not have considered the oral activities useful and also on one of the difficulties experienced with Elluminate. The students' evaluations of their work on the end-of-course assessment elaborate their views on collaborative activity, but generally in a positive way.

\section{The Interviews - First Cohort}

For the interviews with the first cohort ten questions were asked (see Appendix 2). Student C, an Englishman based in the UK, said he had been attracted by the apparent practical orientation of the course and had chosen it because a change of work context meant that he needed more skills in writing documents and presenting to groups to convince and persuade. Student B, a Slovenian accountant based in Slovenia, said her company provided services for new companies starting up "for which good English is required." She wanted to do the course because she didn't have the opportunity to speak English every day. However, although she found the reading activities quite demanding, having to read texts two or three times to understand them, she said she did not find the speaking activities very useful because she does not "have a problem with pronunciation." She became aware of a big difference between the way English is written and how it is spoken and found the biggest challenge was developing new knowledge and learning new skills in English. She also said she had: 
learned younger students' English as a hobby so I have to do a lot of corrections before submitting assignments - not because what is written is wrong but because it has to be written differently for the assignments.

These students met regularly on Skype, which they expressed as enabling them to feel part of a student community. They also found the Elluminate tutorials helped them find their way through the course, although there were technical problems and issues, with one student speaking very quietly and sometimes everyone speaking at the same time. Nevertheless, the students "enjoyed being able to talk and exchange ideas" (Student C), which they felt helped in terms of personal presentation and "softening how you come across" (Student B).

Student B's description of "good English" for work and the contrasting of her written assignments with "younger students' English" indicate an awareness of genres and their appropriacy. This student struggled to get away from the essay genre in her assignments (see Figure 1.3) and appeared, eventually, to achieve this through the collaborative work on the End-of-Course Assessment (Figure 1.4).

In spoken English, "pronunciation" appears to be an important factor for her, since she implies that having good pronunciation obviates the need for practice. In this, she conforms to Jenkins's (2007) emphasis on the importance of accent. At the same time the student expresses awareness of other factors in spoken language: "softening how you come across" which resonates with Louhiala-Salminen and Kankaanranta (2005) and the need for "finding the right expressions" or being able to "convey nuances."

\section{The Interviews - Second Cohort}

The two interviewees were Student D, a Frenchwoman working in a U.K.based company, and Student E, a Japanese woman working in a Japanese company in Kyoto. They both rated the course highly in terms of how it helped them in the workplace. Student E said, "We have foreign employees and clients and need English daily. In most cases, clients prefer English." She felt it was very useful to collaborate with people in other countries, but hard to gather as a group on Elluminate. She found the collaboration with other non-native speakers the most challenging part because of "the different accents and not being familiar with other cultural backgrounds and customs." The students in Japan, who were not in Tokyo (including the interviewee), worked online as a group with students in other countries. Student E said she was familiar with the business tools covered on the course: social, technological, economic, and political analysis (STEP), strengths, weaknesses, opportunities and threats (SWOT) and Porter's Five Forces (Porter, 1985), but had not used them in English. She was not used to the type of test they had to carry out (group discussion), but said "it was not a problem of English but of study approach." This comment illustrates Sonaiya's (2002) point mentioned earlier about teaching methods that force students to adopt ways of behaving which do not fit with their accustomed approaches. From this perspective, as will be seen below from the quotes from students' evaluations, the Japanese students seem to have felt any cultural differences more keenly than the others, with the exception perhaps of the Russian student. However, Student E said she liked the collaborative approach "if it's meant to make a report or presentation." She felt that she improved all her communicative skills "because the course... was very balanced. I believe if I can write logically I can speak 
very effectively in business on the phone, on Skype and face-to-face." She thus saw perfecting her writing as a means towards improved oral communication, as did Student D below.

Student D said she enjoyed the course because it was the first time she was able to exchange views with students with the same problems as her. She found the course useful for her work as she anticipated being promoted to manager and the company she works for has offices in Seoul and Sydney, and she knows "the English is different there." She said she "wasn't sure of her English but soon recognised it was enough," but her "ear was not used to foreign accents and it was good to have a taste of these and to make sure people can understand each other abroad." This student expressed that she had learnt to formalise her business writing and also to be more formal in the spoken context in presentations, for example, and "not to be too friendly to people."

Both these students recognise the impact of the context in which the use of English is occurring, as in the "study approach" and the "foreign accents". As Student $\mathrm{D}$ works in the UK, she may be indicating here that she understands native speakers better than speakers of English as a lingua franca, but if this is the case, she recognises the importance to her of understanding the latter in the work context. The students' comments suggest confidence in their English (as with Student B in the first set of interviews) with justification, since an entry requirement is IELTS 6, but also in recognition of the need in English as a lingua franca expressed by Baker (2009) to focus on the types of communication strategies needed when functioning in multilingual communities - in this case particularly in business communities.

\section{Student Assignments}

The first assignment on the first presentation of the course can be seen in Figure 1.1.

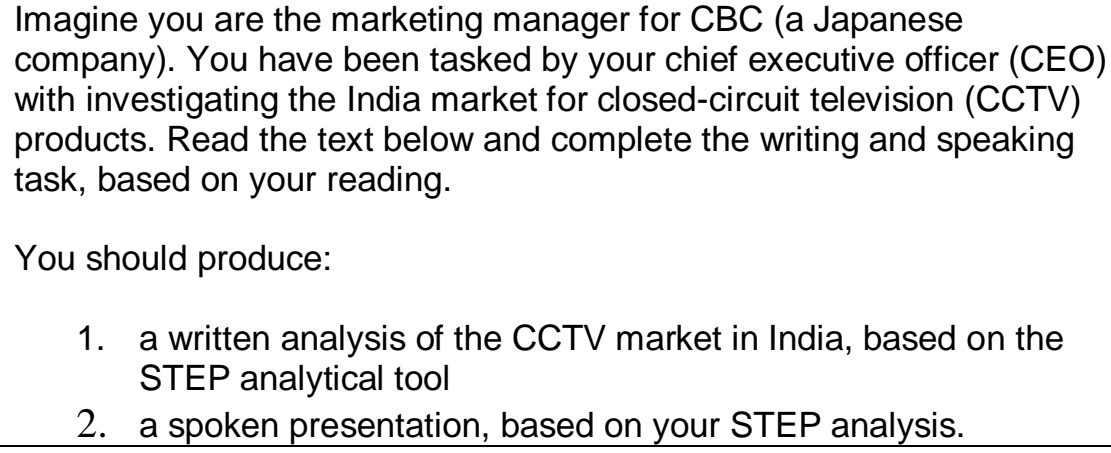

1. a written analysis of the CCTV market in India, based on the STEP analytical tool

2. a spoken presentation, based on your STEP analysis.

Figure 1.1.First assignment.

At this point in the course, the students have looked at a number of texts and how they are produced and structured, been introduced to STEP as a business tool, and produced (in theory at least) a number of short pieces of writing and speaking online.

The assignment gave very different results for two of the students on the first cohort, as can be seen in Figure 1.2 and Figure 1.3 respectively, each representing the student's analysis of the political factors relevant to the CCTV market in India. 


\section{POLITICAL FACTORS}

Knowing that transportation infrastructure is primordial for a modern economy, Indian government invests in CCTVs in order to ease circulation of goods and people.

Good communication routes and security of people, which the use of CCTVs contributes, are also good arguments when trying to attract international investments in India.

Furthermore, government aided projects are likely to sustain Indian economy by creating jobs.

Figure 1.2. Extract one, assignment one, first cohort. Student A, French man based in France.

Political factors sometimes do not go along with economic reasons but
in the field of CCTV can be said differently. Since the growth of
terrorism and crime the need for public security has increased. The
government must provide the means of security: the easiest way is the
use of CCTV. With increased development of technology the setting up
was made possible. The government must take into consideration the
effect of intrusion into private life of people with the use of these
cameras. There is a noticeable growth in the emphasis on the
protection of personal data and all the information gathered with the
CCTV must be considered with extreme care. The use of CCTV in
public places will soon be regulated by law, because the benefits of the
use in society are much larger than the negative effects, which are
often considered and presented by a small group of individuals.

Figure 1.3. Extract two, assignment one, first cohort. Student B Slovenian woman based in Slovenia.

Figure 1.2 and Figure 1.3 present very different textual, ideational, and interpersonal features. Student A has included a heading in capitals followed by three separate points, each contained in one sentence and ideationally representing a distinct factor. The interpersonal relationship is rendered low key by the use of simple present tense and expressions such as "likely to" and "good arguments for". On the other hand, Student B has written a discursive essay-type paragraph over the course of which her argument is developed. The recurring use of the modal "must" gives the impression of someone with a strong conviction to express, and the focus is on the impact of CCTV on personal lives, whereas Student A focuses on factors directly relevant to investment.

The tutor, in her feedback, pointed out to Student B that she had not fulfilled the brief of investigating the market for a particular company. In the End-of-Course Assessment, in which students are required to work collaboratively, Student B's essay style approach, which had persisted through her three assignments, was tempered by collective working, and the joint outcome was a more businesslike document which focused clearly on the aim of the task, this time investment in Peru, also a STEP analysis (their choice). Below is her paragraph on economic factors, as seen in Figure 1.4 . 
Economic View of Food and Drink Market in Peru

All the economies in the world today felt the impact of the world crisis, which started in 2008. The trends in 2007 and 2008

showed strong consumption, large foreign investments and strong export, not only in Peru but also in whole Latin America. Since the crisis, the predictions and trends for GDP growth and consumption and investments show a slowdown in almost all the areas of the economy. In spite of this the emerging markets, like Peru are still very interesting to the global companies.

Figure 1.4. Extract three, End-of-Course Assessment, first cohort.

The paragraph has a heading, the focus is more on the aim of the whole report as the last sentence shows, and the vocabulary GDP, consumption, and investments, contributes to a business genre. In Student B's evaluation of the joint work she wrote:

we both found out how the other person writes and understands text. We discovered that my notes were more describing and A's were more analytical. And later in the same report A's way of thinking was very detailed and analytical. My point of view was more general and connecting.

When interviewed for the research, the student commented on how she had learned about the difference between written and spoken English, and said "I have learned much more than only got an improvement on speaking skills. I found out I have improved significantly on the writing field because I have learnt the techniques on how to write the case studies." She elaborated, "The focus on sentence formation was quite different to what I am used to e.g. noun groups etc."

\section{Students' Evaluations of their End of Course Assessment}

Part one of the End-of-Course Assessment is the collaborative report written by a group of three or four students; Part two is an individual evaluation of the process of production of the report; and Part three is a brief individual presentation from each member of the same group followed by a group discussion. This section looks at the evaluations produced by the students on the second cohort as a means of assessing the level of interchange and establishment of a student community on the course and the effectiveness of the Hallidayan approach to language teaching. Students had been introduced to the genre of evaluation (new to some of them) via the second and third assignments and had been taught what was required for success in this part of the assessment, including the fact that the evaluation did not necessarily need to be positive. Group numbers refer to the groups they were in for the End-ofCourse Assessment.

The evaluations demonstrate that the students participated fully, and on the whole positively, with the collaborative requirements of the course and found these relevant to their language learning and work context (see my italics in the quotes below). 


\section{Collaboration}

The figures below show student quotes on their experience of working collaboratively.

Working remotely and in a collaborative way with colleagues located in different countries where English is not the first language has proven to me how valuable this course is. As the course teaches skills beyond the use of a language, by introducing business tools, it makes the experience more interesting and applicable to real life.

Figure 2.1. Collaboration. Group three, Student F, Argentinian woman based in the UK.

Unfortunately, I realised that each of us, probably due to different level of experience in drafting in a foreign language, had different plans to the manner in which we would build the text. [...] In the end the complete exercise was an interesting study of people behaviour and provided me with a few valuable lessons.

Figure 2.2. Collaboration. Group four, Student G, Polish woman based in the UK.

Having a discussion with other members was a good experience, since it provided me a feeling that we were real consultants and were analysing for a company. On the other hand, there were difficulties. It was challenging to discuss about economy in English. The level of understanding of the texts was different from member to member which made it difficult to discuss the topic deeply.

Figure 2.3. Collaboration. Group two, Student H, Japanese woman based in Tokyo.

These quotes resonate with the English as a lingua franca goals of developing language through shared activities and interests and the ability to come up with diverse strategies mentioned by Canagarajah (2007). The students express appreciation of the application of the activities to the work context. However, several also mentioned communication difficulties in their group. 


\section{Communication}

The figures below illustrate some of the students' perceptions of the communication that took place between them on the module.

Our group consists of one Russian man, two Japanese women and one woman from Arabian Emirates. It was necessary to keep in mind constantly that all of the members of our group were not native speakers, [...] that it is difficult for them to understand those whose English is not native. All of us have different accents. At the beginning of mutual work, the problem of misunderstanding was very critical; we were forced to repeat our thoughts several times. But after a second meeting, the problem decreased in itself. We received the experience of mutual communication and began to understand each other better and the problem disappeared.

Figure 3.1. Communication. Group one, Student I, Russian man based in Moscow.

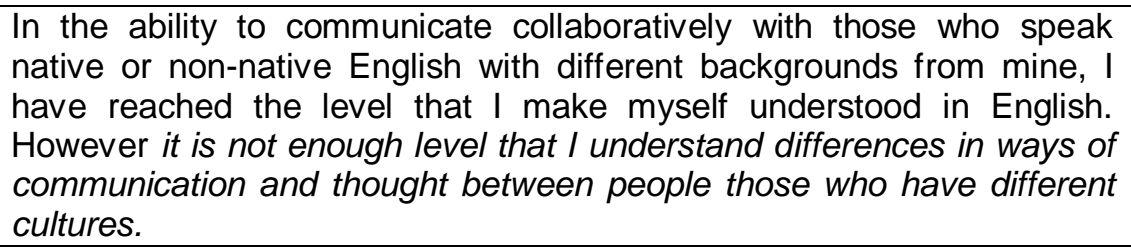

Figure 3.2. Communication. Group one, Student E, Japanese woman based in Kyoto.

In Figure 3.1, the communication difficulty is ascribed to accent and as in the case of Student D, Student I implies that it would be easier for those involved to understand native speakers, suggesting that these students have not moved away from valuing native speaker English, contrary to the thinking in English as a lingua franca that norms in the global world have evolved from this perspective (see for example, Baker, 2009). The student appears to think that all native speakers speak with the same accent whereas those who are not native speakers "have different accents."

In Figure 3.2, from a student in the same group, the student distinguishes between being "understood in English" and understanding "differences in ways of communication and thought" indicating a greater consciousness of cultural difference amongst Japanese students than others, which seems to suggest that they did perceive themselves as culturally other in relation to the European students. It emerges from Figure 3.3. that they were also perceived as being part of a particular culture by Student I.

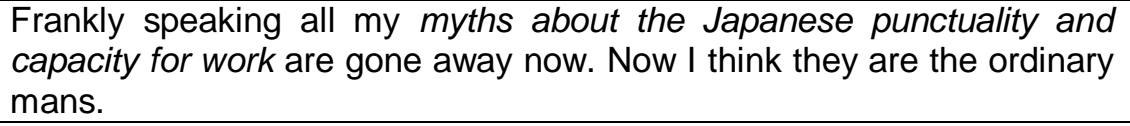

Figure 3.3. Communication. Group one, Student I, Russian man based in Moscow. 
This was the only overtly negative mention of cultural differences in the evaluations. Others stressed the positive effects of difference as long as motivation was present:

After this experience I would say that it is quite easy to produce a
collaborative piece of work with good team members, but it could be an
impossible task if the members have not a team spirit. Furthermore the
best outcomes come compounding people with different characteristics
and profiles but all with the same common denominator: high
motivation.

Figure 3.4. Communication. Group three, Student J Italian woman based in Sweden.

In terms of the language component of the course, although students were not asked specifically to discuss this in their evaluations, several aspects were mentioned in some detail, suggesting that the materials had been effective in transmitting the Hallidayan approach and that the students considered this important.

\section{Language}

The next series of figures illustrates some of the understanding of language gained by students.

$$
\begin{aligned}
& \text { [The course] has showed me that expressing oneself does not have to } \\
& \text { be completed [sic]. Expression can and should be less complicated, } \\
& \text { easy to understand and straight to the point. For example, the use of } \\
& \text { noun groups to keep information condensed is an interesting strategy } \\
& \text { that I now use at work, mostly at meetings when taking notes or writing } \\
& \text { the first draft of a report. I also use them as notes to myself when } \\
& \text { assembling ideas for my future non-profit organisation. }
\end{aligned}
$$

Figure 4.1. Language. Group two, Student K, Haitian based in Tokyo.

In a few video clips from the sessions, I learnt many useful expressions
to propose solutions and these were helpful when meeting with
members of my group. ...And other ways of expressing solutions
helped me to go through the different discussions we had on the texts. I
also learnt that need and have to express a very strong conviction on
behalf of the speaker that the solution is a good one. The word should
expresses a weaker conviction, and could expresses the fact that this is
a possible solution, but not necessarily the only one.

Figure 4.2. Language. Group four, Student L, Italian woman based in Luxembourg, her underlines.

In producing consultancy report... it was necessary to define 'goal' and 'criteria for solution'. Furthermore, in making paragraphs and sentences, I linked between paragraphs and sentences, started with highly generalised supported by detailed information and summary.

Figure 4.3. Language. Group one, Student E, Japanese woman based in Kyoto. 
These comments reflect the functional approach adopted in the materials and the way in which the students applied it in their tasks, and in the case of the first quote, in his work and life. There was no specific mention of language in the guidelines for the task so these inclusions were spontaneous. No other students mentioned language in this way, and all the members of Group three (see Figures 3.4 and 2.1) were very confident in their writing, pointing out that they all had at least 10 years of business experience in challenging functions.

\section{Conclusions}

To return to the questions posed at the start of this paper, taking the question of whether the students would form a virtual community first, it seems that an online community, or online communities developed, and learning took place in those communities. This is clear from the quotes on collaboration and communication from the students' evaluations, the reports produced — of which a small sample was given above - and the answers given in the interviews: Student B "enjoyed being able to talk and exchange ideas." Student D said it was the first time she was able to exchange views with students with the same problems as her. The students were all participants in a business community, via each of their separate workplace communities, and business was definitely a unifying factoring in terms of both motivation - since all students wanted to function well in business-and in terms of rapport between people from similar working environments. They were mostly functioning in multilingual communities and, therefore, recognised the importance of understanding a variety of Englishes. As Student E said, "We have foreign employees and clients and need English daily." Students were simultaneously part of the student group as a whole transnationally and part of their own group of three or four for the purpose of achieving the tasks on the course. Some of the small groups were defined geographically, such as the one in Tokyo. Group four described themselves as "a good European division," but others did not have a geographically unifying factor as they included students on different continents. Language use also varied within groups where there was more than one speaker of a given language. This was the case with the Japanese students in two groups, and the French student and the Italian living in Luxemburg who said they also sometimes communicated in French. In this way local and global intermingled; however, there was a perceptible western/other divide between Japanese and non-Japanese culturally. In spite of the range of student backgrounds among the non-Japanese, both interviews (Student E) and evaluations (Figures 2.3 and 3.2) demonstrate that Japanese students found the course harder and, in that sense, the objective of creating a course equally accessible around the globe has not been fully achieved.

Technology was key to the creation of community, and although several students mentioned difficulties, ultimately they all communicated by one means or another because they had to in order to achieve the required tasks. The issue of one student not having access to broadband would be interesting to explore, but this was not possible as the individual did not make themselves known to us, which in itself raises questions. Were they reluctant to admit to it perceiving it as a lack of status, or did they simply consider it not worth mentioning? It is evident that even in a course such as this (involving people working in business) it is not safe to assume that all students will have that facility. This reflects the point made by Lukhele (2004) with 
reference to students on the African continent who may find themselves at a disadvantage technologically.

Did the course materials fulfil their intended purposes in the eyes of the students? The assignments described above show that those two students gained written communication skills. The fact of having a collaborative assessment at the end of the course appears to have had an impact on students' written and oral communication skills: "We received the experience of mutual communication and began to understand each other better" (Student I); "I have reached the level that I make myself understood in English" (Student E); "We found out how the other person writes and understands text" (Student B). Students also pointed out that they had learnt to apply skills they already had through the medium of English (Student E, in interview). In interviews and evaluations, students demonstrated that they became aware of different ways of using English, both in terms of formal genres for speaking and writing and in terms of how different users operate in the language in their contexts. They mentioned gains such as being able to understand English in different contexts and particularly understanding different accents, as well as the usefulness of making contact with people in similar situations and learning from them. At the same time, Student H, as quoted in Figure 2.3, points out the challenge that discussing economics in another language represents, which flags up the difficulty of creating a course at postgraduate level which can fulfil the dual function of developing students' language and encouraging them to grapple with complex ideas at the same time.

It is evident from their comments that students gained awareness of how texts are constructed and some ability to deconstruct them, but the task of constructing texts of their own did not come easily to some of them and twelve weeks is a relatively short time in which to build a new approach to the use of language. The fact that the course is based on business skills and their use in English was evidently key to its effectiveness. The students that enrolled came to it as people working in management and wanting to function better through the medium of English. As such they did not question the use of English as the language of international business and appeared to buy in to the notion that it is necessary in order to function in business on a global scale. However, there was no evidence that they perceived Business English as a lingua franca as neutral or cultureless and a conduit of their own culture as Kankaanranta and Louhiala-Salminen (2010) describe. On the contrary, the Japanese students, in particular, seemed to perceive a necessity to adapt their culture, at least in terms of the approach taken in the tasks on the course (Student E, in interview). Nevertheless, some of the students saw themselves as building new identities as international business operators, as they described themselves as preparing to work in overseas locations (Students E and D in interviews). One student complained that the course was too oriented towards multinationals and did not provide enough examples of medium and small enterprises. This is a valid and useful criticism, indicating the existence of another local context which should have been acknowledged, but it is one that would be hard to approach in a way that would suit the broad range of contexts the students came from.

In fact, most of the students were already operating in a world where borders, both geographical and linguistic, are crossed all the time via digital media. They are used to operating in more than one language according to the demands of their working and social environment and are comfortable communicating in the virtual dimension on a day-to-day basis, both in writing and orally. Our task, in preparing the course, was made easier by the focus on a particular working context. This also made 
it possible for the students to have a greater stake in the learning process and also more control of the learning environment, since they were able to relate to each other on a professional basis. This motivated them to overcome difficulties they experienced with understanding written material and with oral communication. The virtual learning environment provides a potential space for independent and cooperative learning across time, space, and culture, the third space referred to by Kramsch (as cited by Pennycook in Ricento, 2000, p. 118) above, and also a site for learning where the tutor can disappear or have a very light presence. It also makes it possible for students to use and adapt materials for their own purposes in the way that they approach tasks. The students on these presentations of the course were practised in functioning in more than one language and most were used to circulating freely in the world because of their status as educated and employed individuals. However, if the course were to be taken up in the majority world, the situation might be different. In that sense, the viability of the course has not been tested, and McCarthy et al.'s (2003) question about the possible blurring of cultural and economic distinctions between industrialised and industrialising countries remains unanswered. It would be interesting to see how the course would work in Africa, Asia, or Latin America, or how collaboration would work between students based in developing countries and those in the more developed parts of the world.

The limited amount of data and the fact that very few students had taken the course at the time of the research mean that any conclusions can only be tentative. It would have been useful to interview more of the students, and in greater depth, to gain an understanding of their relationship to the English language and their perception of its usefulness and place in the business world. It would also be of practical relevance for future courses to know more about their attitudes to and perceptions of the different media of communication and how these can best be exploited. However, this small study has given some useful indicators of the issues facing those involved in global online teaching and learning.

\section{References}

Baker, W. (2009). The cultures of English as a lingua franca. TESOL Quarterly, 43(4), 567-592.

Crystal, D. (1997). English as a global language. Cambridge: Cambridge University Press.

Canagarajah, A. S. (2007). Lingua franca English, multilingual communities, and language acquisition. The Modern Language Journal, 91(s1), 923-939.

Connell, L. (2006). Business as usual: The image of the corporation in the cultures of globalisation. In S. Smith (Ed.), Globalisation and its discontents (pp.161180). Cambridge: Ds brewer.

Goodfellow, R., Lea, M., Gonzalez, F., \& Mason, R. (2001). Opportunity and equality: Intercultural and linguistic issues in global online learning. Distance Education, 22(1), 65-84.

Halliday, M. A. K. (1994) An introduction to functional grammar. London: Arnold. Hoffman, T. \& Siebers, L. (Eds.). (2009). World Englishes-Problems, properties and prospects: Selected papers from the 13th IAWE conference. Amsterdam: John Benjamins Publishing.

Jenkins, J. (2007). English as a lingua franca: Attitude and identity. Oxford: Oxford University Press. 
Kankaanranta, A. \& Louhiala-Salminen, L. (2010). "English?-Oh, it's just work!": A study of BELF users' perceptions. English for Specific Purposes, 29(3), 204209.

Leki, I. (2007). Undergraduates in a second language: Challenges and complexities of academic literacy development. Mahwah, NJ: Lawrence Erlbaum.

Louhiala-Salminen, L., Charles, M., \& Kankaanranta, A. (2005). English as a lingua franca in Nordic corporate mergers: Two case companies. English for Specific Purposes, 24, 401-121.

Lukhele, G. (2004). Academic writing in global open distance learning: Case studies of an MBA programme in Ethiopia, Russia and the UK (Unpublished doctoral dissertation). Open University, Milton Keynes, UK.

Luo, Y. \& Shenkar, O. (2006). The multinational corporation as a multilingual community: Language and organization in a global context. Journal of International Business Studies, 37(3), 321-339.

McCarthy, C., Giardina, M.D., Harewood, S.J., \& Park, J-K. (2003). Contesting culture: Identity and curriculum dilemmas in the age of globalization, postcolonialism, and multiplicity, Harvard Educational Review, 73(3), 449462.

Open University LB720/Course book 1, Kerr, R. \& Peters, H. (2010). English communication skills for global managers. Open University.

Open University (2010) The international strategy. Unpublished internal document: Open University.

O'Shea-Poon, T., Erling, E. J., Richrdson, J. \& Hawkins, R. (2009). Ethnicity and academic attainment at the Open University: Summary of research findings and call to action. Unpublished internal document: Open University.

Pennycook, A. (2007). Global Englishes and transcultural flows. New York: Routledge.

Porter, M. E. (1985) Competitive advantage: Creating and sustaining superior performance. New York: Free Press.

Ricento, T. (Ed.). (2000). Ideology, politics and language policies: Focus on English. Amsterdam, The Netherlands: John Benjamins Publishing.

Seidlhofer, B. (2009). Common ground and different realities: world Englishes and English as a lingua franca. World Englishes, 28(2), 236-245.

Smith, S. (2006). Globalisation and its discontents. Cambridge: Ds brewer.

Sonaiya, R. (2002). Autonomous language learning in Africa: A mismatch of cultural assumption. Language, Culture and Curriculum, 15(2), 106-116.

Yakhontova, T. (2001). Textbooks, contexts, and learners. English for Specific Purposes, 20, 397-415.

\section{Author Biography}

Helen Peters is a freelance educational consultant previously employed by The Open University, UK. She is a Doctor of Education with extensive experience in the field of English for Academic Purposes and has worked on course development for and with colleagues and students in the UK and abroad. 


\section{LB720 module survey questions}

\section{Appendix 1 Questionnaire}

\section{Section 1 - Your language and subject area}

q1 - Is English your first language?

O Yes (1)

No (2)

\section{$\mathrm{q} 1 \mathrm{a}-$ What is your first language?}

\section{Section 2 - Motivation and Expectations}

\section{q2 - What was your motivation for studying this module?}

(Please select all that apply)

$\square$ To further my career (1)

$\square$ For personal interest (2)

$\square$ To develop the language I need for successful postgraduate study in English (3)

$\square$ For personal development (4)

$\square$ Other (Please specify):

\section{q3 - How does LB720 fit in with your current study plan?}

(Please select one only)

I am planning to achieve an OU qualification, e.g. Certificate, Diploma or MBA (1)

$\mathrm{O}$ I am planning to take more OU modules but am undecided on whether to aim for a qualification (2)

I only intend to study LB720; I have no intention of future study (3)

I am studying LB720 as preparation for further study at another university or college (5)

I am studying LB720 to help me in my current employment

\section{q4 - How clear was the following information?}

(Please select one only in each row)

\begin{tabular}{|c|c|c|c|c|c|}
\hline & $\begin{array}{l}\text { Very } \\
\text { clear } \\
(1)\end{array}$ & $\begin{array}{l}\text { Quite } \\
\text { clear } \\
(2)\end{array}$ & $\begin{array}{l}\text { Not } \\
\text { very } \\
\text { clear } \\
(3)\end{array}$ & $\begin{array}{l}\text { Not at } \\
\text { all clear } \\
\text { (4) }\end{array}$ & $\begin{array}{l}\text { Not } \\
\text { used } \\
(5)\end{array}$ \\
\hline $\begin{array}{l}\text { Module choice information in OU publications, e.g. } \\
\text { prospectus (1) }\end{array}$ & $\bigcirc$ & $\mathrm{O}$ & O & $\mathrm{O}$ & $\bigcirc$ \\
\hline Module choice information on the OU website (2) & $\mathrm{O}$ & $\mathrm{O}$ & $\mathrm{O}$ & $\mathrm{O}$ & $\mathrm{O}$ \\
\hline $\begin{array}{l}\text { Guidance on module choice from OU members of } \\
\text { staff (3) }\end{array}$ & $\mathrm{O}$ & O & O & $\mathrm{O}$ & $\bigcirc$ \\
\hline $\begin{array}{l}\text { Information for students with a physical/mental } \\
\text { health disability, health condition or specific } \\
\text { learning difficulty (e.g. dyslexia) which affects } \\
\text { ability to study (4) }\end{array}$ & O & O & $\mathrm{O}$ & O & O \\
\hline $\begin{array}{l}\text { Career information advice and guidance related to } \\
\text { LB720 (5) }\end{array}$ & O & O & O & $\mathrm{O}$ & \\
\hline
\end{tabular}


Section 3 - Computer and the Internet

q5 - How often do you use the following for studying LB720?

(Please select one only in each row)

\begin{tabular}{l|c|c|c|c|c|} 
& $\begin{array}{c}\text { All of the } \\
\text { time (1) }\end{array}$ & $\begin{array}{c}\text { Most of the } \\
\text { time (2) }\end{array}$ & $\begin{array}{c}\text { Sometimes } \\
\text { (3) }\end{array}$ & $\begin{array}{c}\text { Not much of the } \\
\text { time (4) }\end{array}$ & $\begin{array}{c}\text { Never } \\
\text { (5) }\end{array}$ \\
\hline A personal computer (1) & $\bigcirc$ & $\bigcirc$ & $\bigcirc$ & $\bigcirc$ & $\bigcirc$ \\
\hline A laptop (2) & $\bigcirc$ & $\bigcirc$ & $\bigcirc$ & $\bigcirc$ & $\bigcirc$ \\
\hline $\begin{array}{l}\text { Other mobile device, e.g. } \\
\text { iPhone. (3) }\end{array}$ & $\bigcirc$ & $\bigcirc$ & $\bigcirc$ & $\bigcirc$ & $\bigcirc$ \\
\hline $\begin{array}{l}\text { A broadband Internet } \\
\text { connection (4) }\end{array}$ & $\bigcirc$ & $\bigcirc$ & $\bigcirc$ & $\bigcirc$ & $\bigcirc$ \\
\hline $\begin{array}{l}\text { A dial-up Internet } \\
\text { connection (5) }\end{array}$ & $\bigcirc$ & $\bigcirc$ & $\bigcirc$ & $\bigcirc$ & $\bigcirc$
\end{tabular}

q6 - How often do you study in the following places?

(Please select one only in each row)

\begin{tabular}{l|c|c|c|c|c|} 
& $\begin{array}{c}\text { All of } \\
\text { the time } \\
(1)\end{array}$ & $\begin{array}{c}\text { Most of } \\
\text { the time } \\
(2)\end{array}$ & $\begin{array}{c}\text { Sometimes } \\
(3)\end{array}$ & $\begin{array}{c}\text { Not much } \\
\text { of the time } \\
(4)\end{array}$ & $\begin{array}{c}\text { Never } \\
(5)\end{array}$ \\
\hline At home (1) & $\bigcirc$ & $\bigcirc$ & $\bigcirc$ & $\bigcirc$ & $\bigcirc$ \\
\hline At work (2) & $\bigcirc$ & $\bigcirc$ & $\bigcirc$ & $\bigcirc$ & $\bigcirc$ \\
\hline In a public library (3) & $\bigcirc$ & $\bigcirc$ & $\bigcirc$ & $\bigcirc$ & $\bigcirc$ \\
\hline In an Internet café (4) & $\bigcirc$ & $\bigcirc$ & $\bigcirc$ & $\bigcirc$ & $\bigcirc$ \\
\hline $\begin{array}{l}\text { Elsewhere. If you study anywhere } \\
\text { lse, please specify: } \\
\text { (5) }\end{array}$ & $\bigcirc$ & $\bigcirc$ & $\bigcirc$ & $\bigcirc$ & $\bigcirc$
\end{tabular}

\section{Section 4 - Workload}

q7 - So far, have you found the academic level of the module:

(Please select one only)

Too high (1)

$\bigcirc$ About right (2)

Too low (3)

q8 - Approximately how many hours per week are you spending on LB720 including completing assignments and participating in conferencing and tutorials?

(Please select one only)

0 $0-4$ hours (1)

5-8 hours (2)

9-12 hours (3)

13-16 hours (4)

17-20 hours (5)

21-24 hours (6)

25+ hours (7)

\section{Section 5 - Your study environment}

Q9 - Please tell us how much you agree or disagree with the following statements, if applicable: 
(Please select one only in each row)

\begin{tabular}{|c|c|c|c|c|c|c|}
\hline & $\begin{array}{l}\text { Strongly } \\
\text { agree (1) }\end{array}$ & $\begin{array}{l}\text { Agree } \\
\text { (2) }\end{array}$ & $\begin{array}{c}\text { Neither } \\
\text { agree or } \\
\text { disagree (3) }\end{array}$ & $\begin{array}{c}\text { Disagree } \\
(4)\end{array}$ & $\begin{array}{l}\text { Strongly } \\
\text { disagree } \\
\text { (5) }\end{array}$ & $\begin{array}{c}\text { Not } \\
\text { applicable } \\
(6)\end{array}$ \\
\hline $\begin{array}{l}\text { The module is more } \\
\text { difficult than I expected } \\
\text { (1) }\end{array}$ & 0 & 0 & 0 & 0 & 0 & 0 \\
\hline $\begin{array}{l}\text { I feel part of a student } \\
\text { community on LB720 } \\
\text { (2) }\end{array}$ & 0 & 0 & 0 & 0 & 0 & 0 \\
\hline $\begin{array}{l}\text { Overall, I understand } \\
\text { what is expected of me } \\
\text { on LB720 (3) }\end{array}$ & 0 & 0 & 0 & 0 & 0 & 0 \\
\hline $\begin{array}{l}\text { I have been able to } \\
\text { access LB720 online } \\
\text { when I needed to (4) }\end{array}$ & 0 & 0 & 0 & 0 & 0 & 0 \\
\hline $\begin{array}{l}\text { I used the study break } \\
\text { built into LB720 to } \\
\text { catch up on my studies } \\
\text { (5) }\end{array}$ & 0 & 0 & 0 & 0 & 0 & 0 \\
\hline
\end{tabular}

Q10 - Are there any ways in which we could help you to plan and manage your study of LB720 more effectively?

O Yes (1)

No (2)

q10a - If ' Yes', please explain in what ways we could help you to plan and manage your studies more effectively:

q10b - If ' No', what have you found particularly helpful in planning and managing your studies?

\section{Section 6 - Teaching material and assessment}

\section{q11 - How useful you have found the following?}

(Please select one only in each row)

\begin{tabular}{|c|c|c|c|c|c|}
\hline & $\begin{array}{c}\text { Very } \\
\text { useful (1) }\end{array}$ & $\begin{array}{c}\text { Quite } \\
\text { useful (2) }\end{array}$ & $\begin{array}{l}\text { Not very } \\
\text { useful (3) }\end{array}$ & $\begin{array}{l}\text { Not at } \\
\text { all } \\
\text { useful } \\
\text { (4) }\end{array}$ & $\begin{array}{c}\text { Not } \\
\text { used } \\
(5)\end{array}$ \\
\hline The main module materials (1) & $\mathrm{O}$ & $\mathrm{O}$ & $O$ & $\mathrm{O}$ & $\mathrm{O}$ \\
\hline The audio and video clips (2) & $\mathrm{O}$ & $\mathrm{O}$ & $\mathrm{O}$ & $\mathrm{O}$ & $\mathrm{O}$ \\
\hline The Elluminate tutorials (3) & $\mathrm{O}$ & $\mathrm{O}$ & $\mathrm{O}$ & $\mathrm{O}$ & $\mathrm{O}$ \\
\hline The Tutor Group Forum (4) & $\mathrm{O}$ & $\mathrm{O}$ & $\mathrm{O}$ & $\mathrm{O}$ & $\mathrm{O}$ \\
\hline The online activities (5) & $\mathrm{O}$ & $\mathrm{O}$ & $\mathrm{O}$ & $\mathrm{O}$ & $\mathrm{O}$ \\
\hline The oral exercises (6) & $\mathrm{O}$ & $\mathrm{O}$ & $\mathrm{O}$ & $\mathrm{O}$ & $\mathrm{O}$ \\
\hline $\begin{array}{l}\text { The activities involving collaboration } \\
\text { with other students ( } 7 \text { ) }\end{array}$ & $\mathrm{O}$ & O & O & O & O \\
\hline The TMA guidelines (8) & $\mathrm{O}$ & $\mathrm{O}$ & $\mathrm{O}$ & $\mathrm{O}$ & $\mathrm{O}$ \\
\hline The library's online resources (9) & $\mathrm{O}$ & $\mathrm{O}$ & O & $\mathrm{O}$ & $\mathrm{O}$ \\
\hline
\end{tabular}


q12 - How easy or difficult you have found the following TMAs:

(Please select one only in each row)

\begin{tabular}{l|c|c|c|c|c|c|} 
& $\begin{array}{c}\text { Very } \\
\text { easy (1) }\end{array}$ & $\begin{array}{c}\text { Quite } \\
\text { easy (2) }\end{array}$ & $\begin{array}{c}\text { Neither easy or } \\
\text { difficult (3) }\end{array}$ & $\begin{array}{c}\text { Not very } \\
\text { easy (4) }\end{array}$ & $\begin{array}{c}\text { Not at all } \\
\text { easy (5) }\end{array}$ & $\begin{array}{c}\text { Did not } \\
\text { complete (6) }\end{array}$ \\
\hline $\begin{array}{l}\text { TMA01 } \\
(1)\end{array}$ & $\bigcirc$ & $\bigcirc$ & $\bigcirc$ & $\bigcirc$ & $\bigcirc$ & $\bigcirc$ \\
\hline $\begin{array}{l}\text { TMA02 } \\
\text { (2) }\end{array}$ & $\bigcirc$ & $\bigcirc$ & $\bigcirc$ & $\bigcirc$ & $\bigcirc$ & $\bigcirc$ \\
\hline $\begin{array}{l}\text { TMA03 } \\
\text { (3) }\end{array}$ & $\bigcirc$ & $\bigcirc$ & $\bigcirc$ & $\bigcirc$ & $\bigcirc$ & $\bigcirc$
\end{tabular}

q13 - Which module activities have you found particularly useful for your learning?

q14 - Which module activities have you found particularly difficult? If possible explain why you found them difficult:

q15 - How useful have you found the language used in the module materials so far?

(Please select one only)

Very useful (1)

Fairly useful (2)

Not very useful (3)

Not at all useful(4)

q16 - What, if any, words or concepts have you found difficult to understand?

q17 - Please add any further comments about your teaching materials and assessment:

\section{Section 7 - Help and support}

Q18 - Please tell us how much you agree or disagree with the following statements:

(Please select one only in each row)

\begin{tabular}{|c|c|c|c|c|c|c|}
\hline & $\begin{array}{r}\text { Strongly } \\
\text { agree (1) }\end{array}$ & $\begin{array}{l}\text { Agree } \\
\text { (2) }\end{array}$ & $\begin{array}{c}\text { Neither } \\
\text { agree or } \\
\text { disagree } \\
\text { (3) }\end{array}$ & $\begin{array}{c}\text { Disagree } \\
(4)\end{array}$ & $\begin{array}{l}\text { Strongly } \\
\text { disagree } \\
(5)\end{array}$ & $\begin{array}{c}\text { Not } \\
\text { applicable/used } \\
\text { (6) }\end{array}$ \\
\hline $\begin{array}{l}\text { Feedback on my assessed } \\
\text { work/TMAs has always } \\
\text { been prompt (1) }\end{array}$ & 0 & 0 & 0 & 0 & 0 & 0 \\
\hline $\begin{array}{l}\text { Feedback on my assessed } \\
\text { work/TMAs has always } \\
\text { been helpful (2) }\end{array}$ & 0 & 0 & 0 & $\mathrm{O}$ & 0 & $\mathrm{O}$ \\
\hline $\begin{array}{l}\text { I am satisfied with the } \\
\text { quality of the online } \\
\text { tutorials (Elluminate) I } \\
\text { have taken part in (3) }\end{array}$ & 0 & $\bigcirc$ & 0 & 0 & 0 & 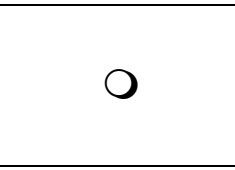 \\
\hline $\begin{array}{l}\text { I am satisfied with the } \\
\text { quality of discussion in } \\
\text { my tutor group forum (4) }\end{array}$ & 0 & 0 & 0 & $\bigcirc$ & 0 & 0 \\
\hline $\begin{array}{l}\text { I receive satisfactory } \\
\text { support for study related } \\
\text { to my physical/mental } \\
\text { disability, health } \\
\text { condition or specific } \\
\text { learning difficulty (e.g. }\end{array}$ & 0 & 0 & 0 & 0 & 0 & 0 \\
\hline
\end{tabular}




\begin{tabular}{l|c|c|c|c|c|c|} 
& & $\begin{array}{c}\text { Neither } \\
\text { agree or } \\
\text { disagree } \\
\text { Strongly }\end{array}$ & $\begin{array}{c}\text { Agree } \\
\text { Disagree } \\
\text { (2) }\end{array}$ & $\begin{array}{c}\text { Strongly } \\
\text { disagree } \\
(5)\end{array}$ & $\begin{array}{c}\text { Not } \\
\text { applicable/used } \\
(6)\end{array}$ \\
\hline dyslexia) (5) & & & & & &
\end{tabular}

\section{Q19 - How do you get the help and support you need to study LB720?}

(Please select all that apply)

$\square$ By emailing my tutor (1)

By talking to my tutor in the tutor group forum (2)

$\square$ Participating in the Elluminate tutorials (3)

From friends, and/or family (4)

From work colleagues (5)

$\square$ In other ways. Please explain: (6)

q20 - Please use the box below to add any further comments you wish to give about your support needs:

\section{Section 8 - Module Overall}

\section{q21 - To what extent do you agree or disagree with the following:}

(Please select one only in each row)

\begin{tabular}{|c|c|c|c|c|c|c|}
\hline & $\begin{array}{l}\text { Definitely } \\
\text { agree (1) }\end{array}$ & $\begin{array}{l}\text { Agree } \\
(2)\end{array}$ & $\begin{array}{c}\text { Neither } \\
\text { agree or } \\
\text { disagree } \\
\text { (3) }\end{array}$ & $\begin{array}{c}\text { Disagree } \\
(4)\end{array}$ & $\begin{array}{l}\text { Definitely } \\
\text { disagree } \\
(5)\end{array}$ & $\begin{array}{c}\text { Not } \\
\text { applicable/used } \\
(6) \\
\end{array}$ \\
\hline $\begin{array}{l}\text { Overall, I am } \\
\text { satisfied with the } \\
\text { quality of this } \\
\text { module }\end{array}$ & $\mathrm{O}$ & 0 & 0 & 0 & 0 & 0 \\
\hline $\begin{array}{l}\text { Overall, I am } \\
\text { satisfied with my } \\
\text { study experience }\end{array}$ & 0 & 0 & 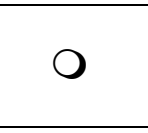 & 0 & 0 & 0 \\
\hline $\begin{array}{l}\text { The module } \\
\text { provided good value } \\
\text { for money }\end{array}$ & 0 & 0 & $\bigcirc$ & 0 & 0 & 0 \\
\hline $\begin{array}{l}\text { I was satisfied with } \\
\text { the support provided } \\
\text { by my tutor/study } \\
\text { adviser on this } \\
\text { module }\end{array}$ & 0 & 0 & 0 & 0 & 0 & 0 \\
\hline $\begin{array}{l}\text { Overall, I was } \\
\text { satisfied with the } \\
\text { teaching materials } \\
\text { provided on this } \\
\text { module }\end{array}$ & & & & & & \\
\hline $\begin{array}{l}\text { The workload on } \\
\text { this module was } \\
\text { higher than I } \\
\text { expected }\end{array}$ & & & & & & \\
\hline $\begin{array}{l}\text { The module met its } \\
\text { stated learning } \\
\text { outcomes }\end{array}$ & & & & & & \\
\hline $\begin{array}{l}\text { I would recommend } \\
\text { this module to other }\end{array}$ & & & & & & \\
\hline
\end{tabular}




\begin{tabular}{l|l|l|c|c|c|c|} 
& $\begin{array}{c}\text { Definitely } \\
\text { agree (1) }\end{array}$ & $\begin{array}{c}\text { Agree } \\
(2)\end{array}$ & $\begin{array}{c}\text { Neither } \\
\text { agree or } \\
\text { disagree } \\
\text { (3) }\end{array}$ & $\begin{array}{c}\text { Disagree } \\
(4)\end{array}$ & $\begin{array}{c}\text { Definitely } \\
\text { disagree } \\
\text { (5) }\end{array}$ & $\begin{array}{c}\text { Not } \\
\text { applicable/used } \\
\text { (6) }\end{array}$ \\
\hline students & & & & & & \\
\hline $\begin{array}{l}\text { The module met my } \\
\text { expectations }\end{array}$ & & & & & & \\
\hline $\begin{array}{l}\text { I enjoyed studying } \\
\text { this module }\end{array}$ & & & & & &
\end{tabular}

q22 - What has been the worst thing about studying LB720 so far?

q23 - What has been the best thing about studying LB720 so far?

It is always useful to illustrate the survey findings in our internal reports and external publications with anonymous quotes from your comments.

Please tick this box if you would rather your comments were not used in this way.

Please do not use my comments [Add box]

We plan to contact some students to learn more about their experience of studying LB720. Would you be happy to participate in a follow up study?

Yes / No

If YES, please write in your email address and contact telephone number so we can get in touch with you

\section{LB720 Interview Questions}

Appendix 2 Interview questions $1^{\text {st }}$ cohort

1. To begin with let's talk about your motivations and expectations of the course:

A. What was your main motivation for studying the course?

B. What courses, if any, did you take before starting LB720

C. Before the course began, how useful was the course choice information? Was there any information regarding your choice of course that was not clear or easily available?

D. Is English your $1^{\text {st }}$ language? If not which is?

2. The next two questions ask about how you use technology to study

A. How often do you use ... for studying the course:

i. A desktop computer

ii. A laptop

iii. Other mobile devices such as an iPhone, Smartphone, eReader

B. Where do you do the majority of your studying? [Follow with, if relevant] How often do you study in the following places:

i. At home

ii. At work 


$\begin{array}{ll}\text { iii. } & \text { In a public library } \\ \text { iv. } & \text { Internet café } \\ \text { v. } & \text { Other place - interviewee to specify }\end{array}$

3. Turning now to the amount of time spent studying

A. On average, how long do you spend each week studying?

B. Which block of learning has had the heaviest workload so far? Why was this?

C. How many hours per week were you spending on this block?

D. Overall has the academic level of the course been too high, too low or about right? Please explain.

4. The course contains a variety of teaching material such as the course materials, audio and video clips, TMA guidelines, website, forum etc. Of all the materials provided on the course so far, which have you found particularly useful?

Which of the materials have not been useful?

How easy or difficult have you found it to get used to the way the course is structured?

Have you found the right balance between business and academic perspectives? Too high/about right/too low?

5. A. Have you used the study break built into LB720 to catch up on your studies?

B. Has the course been easier or more difficult than you expected?

C. Do you feel part of the student community on LB720? Please explain

D. Do you understand what is expected of you on LB720?

E. Have you Been able to access LB720 online when you needed to?

F. Have you found the assessment appropriate for the level and nature of the course?

G. Have you had any difficulties with the language used on the course i.e. the terminology/concepts

6. What do you consider have been the greatest learning challenges - such as understanding concepts, gaining knowledge or developing skills?

How well have the activities in the course supported this?

How easy or difficult have you found the activities? Have you been able to relate the tasks to your workplace? Are they realistic?

How do you manage your studies/how do you approach the materials, e.g. do you read through all the materials in one week and then go back to the first activity?

7. Are there ways in which the University could help you to plan and manage your study on LB720 more effectively?

8. If you have needed help and support how have you gone about getting this? [prompt: by emailing my tutor, by talking to my tutor in the tutor group forum, by communicating with other students in the course forum, participating in the Elluminate tutorials, from friends, work colleagues] 
9. How satisfied are you with:

F. Feedback on your TMAs. Has it always been prompt and helpful?

G. The quality of online tutorials (Elluminate) you have taken part in?

$\mathrm{H}$. The quality of discussion in the forum?

I. If you have needs for study related to physical/mental disability, health condition or specific learning difficulty (e.g. dyslexia)

J. The quality of the course

K. Your study experience

L. The support your tutor provides on LB720

M. How enjoyable the course has been so far?

Is there any additional support you would have liked?

Are you planning to take further course after completing the course? [prompt: are you planning to achieve a qualification?]

10. Is there anything you would like to add about your experience of LB720 so far?

$$
\text { Appendix } 3 \text { Interview questions } 2^{\text {nd }} \text { cohort }
$$

1. What were the main things you learnt from LB720, in terms of knowledge; skills; language?

2. What did you learn that could be useful to you in your present or future career?

3. What did you learn about distance communication while on the course?

4. What did you learn from communicating with students from many countries?

5. Do you think studying LB720 will have any effect on your career? If so in what way? Can you give examples? 